\title{
Economic Evaluation of Public Policies Aiming the Reduction of Greenhouse Gas Emissions in Brazil
}

\author{
Joaquim Bento de Souza Ferreira Filho \\ Universidade de São Paulo - USP \\ Marcelo Theoto Rocha \\ Centro de Estudos Avançados em Economia Aplicada
}

\begin{abstract}
In this paper a static, inter-regional and bottom-up general equilibrium model of greenhouse gas emissions in Brazil is used to analyze the impact of different types of carbon taxes on the economy. The core database is calibrated with Brazilian economic data from 1996, while the emissions module is based on the Brazilian Initial National Communication to the United Nations Convention about Global Climate Change for the 1994 reference year. The gas module in the model comprises all known sources of greenhouse gases emissions except emissions from land use change (deforestation). The simulations comprise scenarios with carbon taxes on emissions, either on fuel use or on the activity level of industries. Results show that taxing activities is more relevant for greenhouse gases emissions reductions in Brazil than just taxing fuel use, due to the importance of activity related emissions in the Brazilian emissions matrix. Livestock is found to be one of the most important emission sectors in Brazil. Carbon tax on activities, however, generates the higher increase in food prices, with negative implications for poverty alleviation. Different carbon tax schemes would also have different

\footnotetext{
*Corresponding address: Joaquim Bento de Souza Ferreira Filho: Professor, Escola Superior de Agricultura "Luiz de Queiroz"-ESALQ. Universidade de São Paulo - USP. Depto. Economia, Sociologia e Administração. Av. Pádua Dias, 11. Piracicaba, SP. Brazil. CEP - 13418-900. email: jbsferre@esalq.usp.br, Marcelo Theoto Rocha: PhD, researcher at the Centro de Estudos Avançados em Economia Aplicada - CEPEA/ESALQ/USP. Av. Pádua Dias, 11. Caixa Postal 132. CEP: 13400-970 Piracicaba SP. Brazil. Email: matrocha@esalq.usp.br (2008-Center for International Economics, Sejong Institution, All Rights Reserved.
} 
regional impacts inside Brazil, with taxation on fuels harming more the Southeast and Northeast regions, and taxation on activity levels affecting negatively more the South and Center west regions.

- JEL classification: Q52, Q58, C68

- Key words: greenhouse gas emissions, carbon tax, general equilibrium models, Brazil

\section{Introduction}

According to the International Panel on Climate Change (IPCC 2001a) the change in the concentration of greenhouse gases in the atmosphere can cause an increase in the average temperature of the Earth of 1.4 to $5.8^{\circ}$ Celsius in the next one hundred years. The United Nations, through the Framework Convention on Climate Change is aiming for the "stabilization of concentration of greenhouse gases in the atmosphere at a level that avoid a dangerous human interference in the climate system". In the Conference of the Parties meetings (COP) international agreements between countries are discussed, in order to meet the targets established in the Convention. Among these agreements is the Kyoto Protocol (UNFCCC, 2001b), which establishes reductions targets for emissions for countries in the Annex I, for the first period of commitment, from the year 2008 to 2012.

Although Brazil is not included in the Annex I countries, and so does not have mandatory reduction targets for emissions in the first period, the country has formulated and implemented national programs with the aim of meeting its compromises in the context of the Convention which include actions to mitigate the climate change and reduce the human emissions of green house gases (GHG). ${ }^{1}$ However, the present state of negotiations in the Climate Conventions brought to the discussions the need for some developing countries, like Brazil, China and India to have some kind of emissions reductions targets in the future, which could come from different sources.

The share of renewable energy in the Brazilian energy supply matrix is relatively high, as it can be seen in Figure 1. Biomass and other renewable energy sources account for about 46 per cent of total energy supply in the country in the year 2002 (Balanço Energético de Emissões, Ministério da Ciência e Tecnologia). Petroleum,

\footnotetext{
${ }^{1}$ Among the most important of these programs is the Programa Nacional do Álcool - PROALCOOL
} (National Ethanol Program). 
Figure 1. Brazilian Energy Matrix, by Energy Source

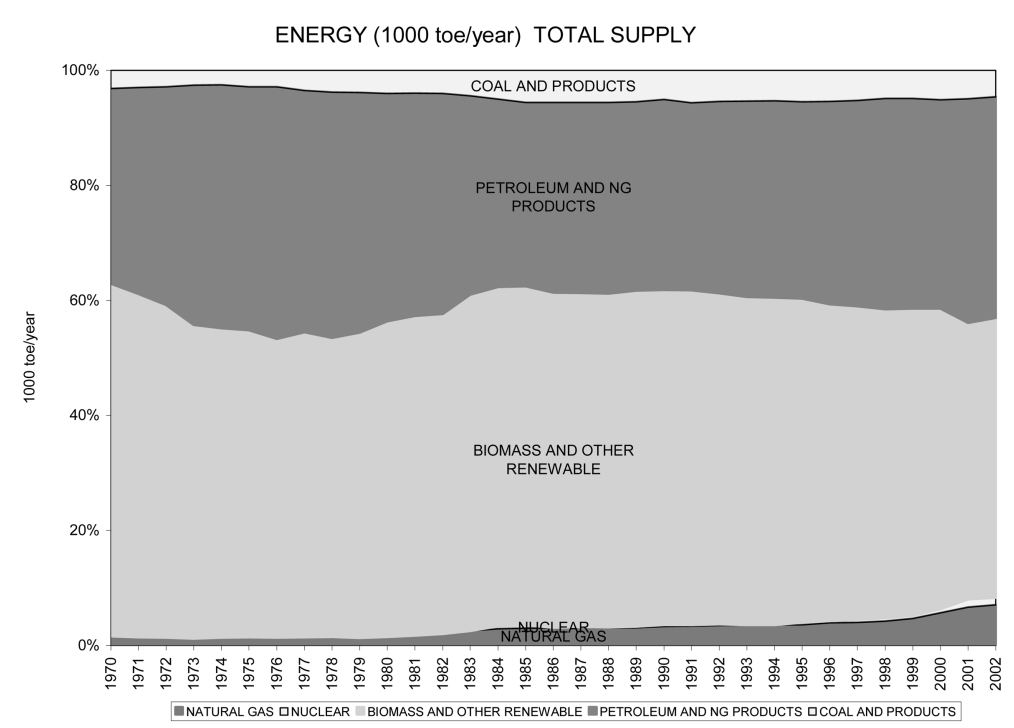

Source: Balanço Energético (BENEMIS). Availabe at http://ecen.com/ftp_pag/download.htm

gas and coal products are responsible for almost all the rest for energy supply, but for a small share of nuclear energy.

Besides the emissions derived from non renewable fossil sources, another very important source of greenhouse gases emissions in Brazil is related to deforestation. According to the Brazilian Initial National Communication to the United Nations Convention about Global Climate Change (Ministério da Ciência e Tecnologia, 2004) these emissions are actually the most important source of emissions in Brazil, accounting for about 80 per cent of total CO2 emissions in 1994, or 58 per cent of total emissions in terms of $\mathrm{CO} 2$ equivalents in the same year.

Even though deforestation control policies are among the most important policies on the Brazilian agenda for emissions control, there is also important scope for policies to reduce emissions coming from other sources, as it can be inferred by the difference in the figures on $\mathrm{CO} 2$ emissions and $\mathrm{CO} 2$ equivalent emissions in deforestation quoted above. The emission of $\mathrm{CO} 2$ and other gases with high Global Warming Potential (GWP), like the $\mathrm{CH} 4$, associated with the production activities in the economy are also of interest for emissions control policies. This study offers an initial assessment of the impacts upon the Brazilian economy of eventual targets on emissions reductions coming from sources other than deforestation. 


\section{Objective}

The main goal of this paper is to quantify the effects on the Brazilian economy of the introduction of public policies aiming to the reduction of greenhouse gases emissions on the economic activities other than deforestation. Namely, the paper will analyze the introduction of a carbon tax on the economy, in different scenarios. For this purpose a general equilibrium model of the Brazilian economy is developed to simulate the effects of that kind of policies, namely the quantitative restrictions on emissions. The model has a gas emissions module, which interacts with the core model equations.

The next sections describe the main characteristics of the model, as well as the database used.

\section{Literature Review}

The Brazilian literature has only a few studies which evaluate quantitatively the effects of greenhouse gases' emissions reduction policies. Among them, Tourinho et al. (2003) analyzed the main economic impacts of a policy of emissions reductions, using a static general equilibrium model of Brazil. The authors analyzed three different scenarios, with different values of a carbon tax (US\$3, US\$ 10 and US\$ 20 per ton of carbon equivalent). The results showed a small impact over total emissions, with the reduction falling between 0.198 per cent and 1.36 per cent. Transport, energy and sugar are the sectors which show the highest reductions in emissions levels, while con- struction is the sector which shows the largest increase in emissions. In this paper, however, emissions are accounted as $\mathrm{CO} 2$ emissions, and not in $\mathrm{CO} 2$ equivalents, which is the most appropriate measure for greenhouse effects analysis. According to the author's methodology, the combined emissions of Transport and Iron production sectors, for example, are responsible for about 50 per cent of the total $\mathrm{CO} 2$ emissions in the economy. As it will be seen later, however, using the carbon equivalent concept substantially changes this result.

Lopes (2003) also used a general equilibrium model to analyze the effects of taxing emissions on the Brazilian economy. This author focused more specifically on the use of primary factors in this context, and also on the issues of substitution between energy, capital and labor. The results of a preliminary version of the model showed that a reduction in emissions is related to a fall in the aggregate activity level in the country, which was, in turn, mainly caused by the contraction in the energy 
intensive sectors. The authors also conclude that the fall in emissions is caused by substitution in energy sources towards coal and natural gas which weren't taxed in the analyzed scenarios. The mentioned study, then, concentrates the focus of the analyses on energy substitution, overlooking the importance for the Brazilian economy of emissions linked to agricultural and industrial production.

Hilgemberg et al. (2005) used an inter-regional input-output model to quantify the $\mathrm{CO} 2$ emissions in the use of natural gas, ethanol and petroleum products in six Brazilian regions, and the impacts of emissions reductions policies. Their analysis had a regional focus, and concluded that the northeast regions would be specially affected (negatively) by those policies. The authors emphasize the importance of the interdependence of the Northeast region in the interregional economic system in Brazil, although the importance of the region in the total economy is relatively small.

None of the previous cited studies used the new database issued by the Ministry of Science and Technology used in this study, which constitutes the official Brazilian Initial National Communication to the United Nations Convention about Global Climate Change.

\section{Methodology}

An applied general equilibrium (AGE) model of the Brazilian economy is used for the abovementioned analysis. It is a static, inter-regional bottom-up model, ${ }^{2}$ derived from the MMRF-GREEN model of Australia. A thorough description of the MMRF-GREEN model can be found in Adams, Horridge and Witwer (2002). The model was modified and calibrated for the Brazilian economy, with the main modification being the introduction in the model of mechanism for substitution of ethanol/gasoethanol ${ }^{3}$ for other fuels, a characteristic feature of the Brazilian fuel market which was magnified recently by the introduction in the country of the flexfuel engines ${ }^{4}$ for vehicles.

\footnotetext{
${ }^{2}$ In the AGE literature the term "bottom-up" as opposed to "top-down" has a different meaning than in the greenhouse gases literature. A "bottom-up" interregional AGE model is one where the regions are actually modeled as individual regions, which are linked to each other by a trade matrix. The model solves first for these regions, being the national results an aggregate of the regional ones. The "top-down" version solves first for the national models, and the results are further disaggregated at national level usually through the use of shares.

${ }^{3}$ Note that in Brazil the final consumption fuel by households is gasoethanol, a mix of $75 \%$ of pure gasoline and $25 \%$ of ethanol. Gasoline is then an input in the gasoethanol production.

${ }^{4}$ Flexfuel engines can use as fuel gasoline, ethanol, or any blend of both.
} 
The present version of the model has 38 activities and products, with each activity producing only one product, and five aggregated regions inside Brazil. The aggregation focuses on the identification of the main fuels, namely gas, combustible oil, gasoline, ethanol, coal and gas for domestic use (GLP), included in the model in Other Refined Products. In this section the main characteristics of the model are described.

\section{A. The General Equilibrium Model}

The model has two main equations blocks: the block describing the core economy, and the gas emissions block. This separation, of course, is merely expository, since the two blocks operate as one. Optimizing agents' behavior underpins the equilibrium in product and factor markets, in a perfectly competitive setting. Labor demand at the national level is determined by demographic variables (outside the model), and capital supply depends on rates of return of activities. Labor and capital are allowed to flow between regions in such a way that the factor stocks in each region reflects labor demands and relative capital returns. The perfect competition hypothesis implies the equality of prices and marginal costs in each sector inside each region. Demand equals supply in all markets. ${ }^{5}$

On the production side, input demand and primary factors are combined to produce goods. A nested production tree uses a Leontief formulation for combining the composite/imported composite input and the composite primary factor. In the second level of the production tree the usual Armington formulation applies for imported and domestically produced inputs, while primary factors land, labor and capital are combined by a CES function to produce the composite primary factor. And, finally, the domestic products are also CES aggregates of products from five domestic origins.

Household demands are modeled through the Linear Expenditure System. Again, the products are CES aggregates between domestic and imported products, and the domestic products are a CES aggregate of the five regional origins inside the country. Exports face a negatively sloped demand curve.

\section{B. The Greenhouse Emissions Equations Block}

This block of equations links the gas emissions in the economy to the general

\footnotetext{
${ }^{5}$ Disequilibrium in the labor market is a possible closure for this model, but not used in this paper. The option actually used in the closure ties up labor supply at regional level to the inter-regional labor migration movements.
} 
economic system. Broadly speaking this set of equations comprises a module of energy accounting and gas emissions, which accounts in detail the gas emissions in each industry and each region; mechanisms that allow the endogenous treatment of the effects of abatement actions in response to the introduction of specific policies; and a mechanism that allows the explicit treatment of the ethanol/gasoethanol substitution in the Brazilian economy.

The model distinguishes the emissions in detail, according to the emitting agent (industries plus the residential sector), the emitting region, and the emitting sector. The emissions can be associated to the energy consumption in each sector, or to the activity level of sectors (not linked to energy consumption, or fuel use), which is an important source of emissions for the Brazilian economy. Agriculture is the most important sector in emissions linked to the activity level in Brazil, as it will be seen.

The emissions in fuel use are modeled as directly proportional to fuel use. To deal with the recent introduction in Brazil of the flexfuel technology, which allows vehicles to use gasoethanol, ethanol or any blend of both, a specific substitution module was introduced, for household consumption. ${ }^{6}$ In this module, households consume an ethanol/gasoethanol composite, ${ }^{7}$ whose composition depends on relative prices, and is intermediated by a substitution parameter. This parameter (the elasticity of substitution) is parameterized in the simulations, since its value is unknown. Note that this system aims to reproduce the presence in the Brazilian fleet of different types of engines, which can use gasoethanol, ethanol or both (the flex-fuel engines). The cheaper ethanol is relatively to gasoethanol the larger the selling of flex fuel or ethanol engine cars relative to gasoethanol engine cars, and the larger the use of ethanol relative to gasoethanol.

\section{The Core Model and the Gas Emissions Database}

As mentioned previously, the model has two main databases: the core database and the gas emissions database. The core model database uses information from the Brazilian 1996 input-output table ${ }^{8}$ and other surveys, like the 1996 Brazilian

\footnotetext{
${ }^{6}$ The scope for this substitution is very small in intermediate consumption, since the bulk of the ethanol used for this purpose is for mixing with gasoline, which is done at fixed coefficients regulated by law.

${ }^{7}$ This composite is a CES aggregate between ethanol and gasoethanol, with a specific substitution elasticity parameter.

${ }^{8}$ This is the last official input-output table in Brazil.
} 
Agricultural Census (IBGE, 1996) and the 1996 Brazilian Household Survey (IBGE, 1996a). The gas emissions database is elaborated based on the Brazilian Initial National Communication to the United Nations Convention about Global Climate Change (Ministério da Ciência e Tecnologia, 2004) for the 1994 reference year. The consolidation of those two databases is an important part of this project, and is described in more detail bellow.

The gas emissions database is organized by type of gas and emitting sector. From an emissions origination perspective by each productive sector, part of the emissions are originated in fuel use, and part related to the level of activity of each sector. This is an important distinction from a modeling point of view, since fuel use represents an intermediate input demand, while emissions related to the activity level are not related to any specific input. The first step in the database preparation, then, consisted in allocating the emissions to each sector in the input-output (IO) matrix, according to its origin (intermediate consumption or activity). Then the emissions linked to fuel use were distributed to each sector according to its proportion in the use of each fuel, information gathered directly from the input-output tables.

For the emissions linked to the activity level of the sectors, however, an agreement between the information from the National Communication and the IO tables had to be done. In some cases the allocation is clear, as is the case of fugitive emissions in the Mining sector, which can be allocated directly to the correspondent sector in IO table. In other cases, however, the allocation it's much less clear, and required many different assumptions in several different situations. ${ }^{9}$

The emissions originating in fossil fuels burning were associated basically to six different fuels: gas, coal, gasoline, combustible oil, and gas for residential use (Other Refined Products). The different production activities in the model, then, having different energy use matrices, have also distinct emissions patterns. Besides the productive sectors in the model, another emitting sector is the final demand, which encompasses both the household and the government ${ }^{10}$ demands, aggregated under the Residential use. And, finally, it should be stressed that emissions related to land use change (deforestation) were not accounted for in this paper, since they are not associated to the productive sectors in the IO table.

Table 1 brings the result of the allocation of the $\mathrm{CO} 2$ equivalent emissions by

\footnotetext{
${ }^{9}$ The details about this process were omitted to avoid cultter.

${ }^{10}$ Note, however, that the government just uses Services.
} 
Table 1. Emissions Matrix by Production Sector. Gg of CO2 Equivalent

\begin{tabular}{|c|c|c|c|c|c|c|c|c|}
\hline Sector & $\begin{array}{l}\text { Broad } \\
\text { sector }\end{array}$ & $\begin{array}{c}\text { Oil and gas } \\
\text { extraction (Gas) }\end{array}$ & Coal & Gasoline & $\begin{array}{l}\text { Combustible } \\
\text { oil }\end{array}$ & $\begin{array}{l}\text { Other refined } \\
\text { products }\end{array}$ & Activity & Total \\
\hline Rice & Agriculture & 0 & 0 & 0 & 368.0 & 11.7 & 15828.5 & 16208.1 \\
\hline Cotton & Agriculture & 0 & 0 & 0 & 87.2 & 2.8 & 850.4 & 940.4 \\
\hline Soybeans & Agriculture & 0 & 0 & 0 & 997.1 & 31.6 & 22058.7 & 23087.5 \\
\hline SugarCane & Agriculture & 0 & 0 & 0 & 1068.2 & 33.9 & 10821.5 & 11923.5 \\
\hline Livestock & Livestock & 0 & 0 & 0 & 1347.5 & 42.7 & 220275.9 & 221666.2 \\
\hline RawMilk & Livestock & 0 & 0 & 0 & 935.0 & 29.6 & 39438.4 & 40403.1 \\
\hline Poultry & Livestock & 0 & 0 & 0 & 780.7 & 24.7 & 2893.0 & 3698.4 \\
\hline Other Animal & Livestock & 0 & 0 & 0 & 526.8 & 16.7 & 22956.9 & 23500.4 \\
\hline Forestry & Forestry & 0 & 0 & 0 & 236.3 & 7.5 & -46473.9 & -46230.2 \\
\hline Other Agriculture & Agriculture & 0 & 0 & 0 & 6219.0 & 197.6 & 34038.6 & 40455.2 \\
\hline Mineral Extraction & Mining & 0 & 44.3 & 0 & 3482.4 & 125.4 & 0 & 3652.1 \\
\hline Petrol Gas Extract & Mining & 0 & 601.4 & 0 & 588.3 & 22.2 & 4884.7 & 6096.5 \\
\hline Coal Others & Mining & 0 & 34.4 & 0 & 20.8 & 0.8 & 2472.2 & 2528.2 \\
\hline Non Metal Miner & Metallurgy & 4.5 & 686.2 & 0 & 6320.0 & 160.4 & 13489.0 & 20660.1 \\
\hline Iron Metallurgy & Metallurgy & 0 & 37964.6 & 0 & 2393.2 & 142.8 & 0 & 40500.6 \\
\hline Non Ferrous Metal & Metallurgy & 0 & 19.0 & 0 & 546.5 & 28.9 & 4447.3 & 5041.7 \\
\hline Other Metallurgy & Metallurgy & 0 & 1136.9 & 0 & 1468.6 & 119.8 & 0 & 2725.2 \\
\hline Machines Vehicles & Manufact & 0 & 38.1 & 0 & 2023.4 & 398.8 & 162.5 & 2622.9 \\
\hline Eletric Material & Manufact & 0 & 2.8 & 0 & 360.8 & 189.4 & 0 & 553.0 \\
\hline Eletric Equipment & Manufact & 0 & 0.2 & 0 & 203.4 & 21.2 & 0 & 224.7 \\
\hline Paper Graphic & Manufact & 0 & 0 & 0 & 2793.6 & 97.6 & 0 & 2891.2 \\
\hline Chemicals & Manufact & 5642.8 & 215.2 & 0.1 & 2406.2 & 1062.5 & 7326.0 & 16652.9 \\
\hline
\end{tabular}


Table 1. Continued

\begin{tabular}{|c|c|c|c|c|c|c|c|c|}
\hline Sector & $\begin{array}{l}\text { Broad } \\
\text { sector }\end{array}$ & $\begin{array}{c}\text { Oil and gas } \\
\text { extraction (Gas) }\end{array}$ & Coal & Gasoline & $\begin{array}{c}\text { Combustible } \\
\text { oil }\end{array}$ & $\begin{array}{l}\text { Other refined } \\
\text { products }\end{array}$ & Activity & Total \\
\hline Other Chemicals & Manufact & 236.9 & 366.5 & 0 & 1377.0 & 197.7 & 250.0 & 2428.0 \\
\hline Ethanol & Ethanol & 0 & 0.3 & 0 & 1179.9 & 43.0 & 0 & 1223.3 \\
\hline Gasoline & FossilFuels & 6920.1 & 0 & 0 & 1568.0 & 1090.8 & 0 & 9578.9 \\
\hline Combustible Oil & FossilFuels & 8038.9 & 0 & 0 & 1821.5 & 1267.1 & 0 & 11127.5 \\
\hline Other Refined Prod & FossilFuels & 6961.7 & 16.6 & 0 & 1593.4 & 1098.6 & 0 & 9670.3 \\
\hline Basic Petrochemic & Manufact & 7585.2 & 46.5 & 0 & 1772.7 & 1199.1 & 0 & 10603.5 \\
\hline Gasoethanol & Gasoethanol & 0 & 0 & 27221.6 & 0 & 0 & 0 & 27221.6 \\
\hline Fertilizers & Manufact & 65.5 & 210.6 & 0 & 300.8 & 101.8 & 0 & 678.8 \\
\hline Textiles & Manufact & 7.8 & 0 & 1.0 & 1178.8 & 55.5 & 0 & 1243.1 \\
\hline Food Beverage & Food & 0 & 4.2 & 0 & 6379.4 & 194.0 & 0 & 6577.7 \\
\hline Other Industries & Manufact & 369.4 & 8.1 & 272.2 & 3702.7 & 201.6 & 0 & 4554.0 \\
\hline Civil Construction & Services & 0 & 0 & 0 & 5368.1 & 804.4 & 0 & 6172.6 \\
\hline SIUP* & Services & 37.8 & 658.6 & 0 & 2555.7 & 55.0 & 20626.0 & 23933.1 \\
\hline Trade & Services & 0 & 80.2 & 66.2 & 4993.0 & 172.2 & 0 & 5311.6 \\
\hline Transport & Services & 0 & 0 & 40.8 & 37909.6 & 2934.9 & 0 & 40885.2 \\
\hline Services & Services & 48.3 & 55.3 & 2042.1 & 8476.8 & 732.3 & 0 & 11354.8 \\
\hline Residential & Residential & 0 & 0 & 0 & 27.7 & 4246.4 & 0 & 4274.1 \\
\hline
\end{tabular}

*SIUP - Public utilities industrial services 
sector into the model. ${ }^{11}$ In this table each specific gas ${ }^{12}$ emissions was transformed in $\mathrm{CO} 2$ equivalent through the use of technical coefficients of transformation (GWP). As it can be seen from Table 1, most of the emissions in the Brazilian economy are related to the sector's activity level, and not to fuel use. In terms of emissions originating in fuel use, the combustible oil is the main emitting fuel. It should also be noted that the emissions in the use of gasoline do not appear associated to the final demand (Residential), but mainly to the Gasoline sector. This is due to the fact that in Brazil the final demand uses Gasoethanol, produced from Gasoline and Ethanol, ${ }^{13}$ as mentioned before.

As it can be seen in Table 1, Agriculture is one of the most important emitting sectors in Brazil, in terms of $\mathrm{CO} 2$ equivalents, and in particular the Livestock sector (CH4 emissions). This fact has important regional consequences for the emission inside Brazil. Table 2 shows that the Center west region of Brazil (CW), although responsible for about 5.4 per cent of total value of production in the country, is responsible for about 26.1 per cent of total $\mathrm{CO} 2$ equivalents on $\mathrm{CH} 4$ and 20.1 per cent in $\mathrm{N} 2 \mathrm{O}$ emissions in Brazil. This is due to the high share of Livestock production in the region, which mounted to about 33.2 per cent of total Livestock sector production in Brazil in the base year. ${ }^{14}$ These two gases account for 90.7 per cent of total $\mathrm{CO} 2$ equivalent emissions in the $\mathrm{CW}$ region in Brazil.

Actually, the $\mathrm{CO} 2$ (direct) emissions are the most important source of emissions in Brazil only in the Southeast (SE), the most industrialized region in Brazil, which includes the states of Sao Paulo, Minas Gerais and Rio de Janeiro. These emissions are mainly associated to the burning of combustible oil, which is concentrated in the states of the region, mainly Sao Paulo. For all the other regions the $\mathrm{CO} 2$ equivalent emissions in $\mathrm{CH} 4$ are the main emissions.

And, finally, regarding the above information, it should be stressed again that emissions from deforestation are not covered here.

\footnotetext{
${ }^{11}$ Equivalent tables with emissions by type of gas and regions are also available, but now shown here.

${ }^{12}$ The gases accounted for are: $\mathrm{CO} 2, \mathrm{CH} 4, \mathrm{~N} 2 \mathrm{O}, \mathrm{HFC} 23, \mathrm{HFC} 134 \mathrm{a}, \mathrm{CF} 4, \mathrm{C} 2 \mathrm{~F} 6$, and SF6

${ }^{13}$ Actually, in the Brazilian 1996 IO tables gasoethanol is produced by the Trade sector. However, this is a margins sector, and this formulation wouldn't be appropriate. The database was then adjusted in order to make the intermediate consumption of gasoline appear mainly in the gasoethanol producing sector, which combines ethanol and gasoline to produce gasoethanol sold to the households (Residential).

${ }^{14}$ The conversion of each specific gas to $\mathrm{CO} 2$ equivalents was done using the Global Warming Potential (GWP) coefficients, which values were: CO2 (1); CH4 (21); N2O (310); HFC23 (11700); HFC134a (1300); CF4 (6500); C2F6 (9200); and SF6 (23900).
} 
Table 2. $\mathrm{CO} 2$ Equivalent Emissions according to Regions in Brazil. Gg of $\mathrm{CO} 2$ Equivalent

\begin{tabular}{lrrrrr}
\hline & \multicolumn{5}{c}{ Region } \\
\hline Gas type & \multicolumn{1}{c}{ 1 N } & $2 \mathrm{NE}$ & \multicolumn{1}{c}{$3 \mathrm{SE}$} & $4 \mathrm{~S}$ & $5 \mathrm{CW}$ \\
\hline $1 \mathrm{CO} 2$ & 3878 & 21085 & 155049 & 16594 & 9833 \\
$2 \mathrm{CH} 4$ & 28750 & 30829 & 71035 & 45854 & 62275 \\
$3 \mathrm{~N} 2 \mathrm{O}$ & 14324 & 20017 & 53760 & 45121 & 33638 \\
$4 \mathrm{HFC} 23$ & 13 & 107 & 1505 & 198 & 13 \\
$5 \mathrm{HFC} 134 \mathrm{a}$ & 1 & 2 & 141 & 17 & 0 \\
$6 \mathrm{CF} 4$ & 201 & 195 & 1752 & 68 & 26 \\
$7 \mathrm{C} 2 \mathrm{~F} 6$ & 28 & 27 & 244 & 10 & 4 \\
$8 \mathrm{SF} 6$ & 3 & 5 & 27 & 4 & 4 \\
Share of the region in the total & 0.032 & 0.091 & 0.670 & 0.154 & 0.054 \\
value of production & & & & & \\
\hline
\end{tabular}

\section{The Simulations}

The main goal of the paper is to analyze the effects of different carbon taxation schemes on the Brazilian economy. For this purpose, three main schemes will be evaluated: a carbon tax with incidence only on fossil fuels, a carbon tax with incidence on non-fossil fuel sources, and a more comprehensive approach combining the first two. Sensitivity analysis will be also performed with the value of a key parameter.

The mechanisms by which those different tax scheme feed into the main core model are as follows. As noted before, the emissions in the model are basically of two types: those originating in the burning of fossil fuels, and those linked to the level of activities of sectors. In the case of a tax being introduced in the use of fossil fuels, it is translated by the model into a tax on fuels. In the case of a tax being introduced on emissions originating on the sector's activity level, the carbon tax is converted into a tax on each emitting sector's product. In both cases this procedure is necessary since all taxation in the model is done through an indirect tax system over products flows. ${ }^{15}$

Three scenarios are simulated. In all three scenarios a carbon tax of $\mathrm{R} \$ 10 / \mathrm{ton}^{16}$ of $\mathrm{CO} 2$ equivalent emissions is introduced. The difference across them is the way

\footnotetext{
${ }^{15}$ Note that, in this formulation, it is not possible to abate emissions per unit of output due to input substitution other than fuel, which can be a restrictive formulation for some sectors.

${ }^{16} \mathrm{R} \$ 10$ is equivalent to approximately US\$9.63, in 1996 values.
} 
of incidence of the tax. In the first scenario (CARBTAX05) the tax incidence is on fuel use only. In the second scenario (CARBTXAT) the incidence in on the activity level of the producing sectors only. And in the third scenario (CARBTX05x) the incidence of the carbon tax is on both fossil fuels use and the activity level.

In all three scenarios describe above the elasticity of substitution between gasoethanol/ethanol has value 0.5 . The value of this elasticity of substitution between will be parameterized with value 1.0 in another simulation, for the sake of sensitivity analysis. As noticed previously, there are no estimates to date for the substitution parameter gasoethanol/ethanol in Brazil. Since the share of the fleet of non-flexfuels cars in Brazil is still large, the value of this parameter is expected to increase with the size of the fleet of flexfuel cars.

\section{Model's Closure}

The capital stock in the economy is determined endogenously, and adjusts to equalize the rate of return across activities. If the rate of return increases in one activity, the capital stock also accumulates, to reduce that rate. Investment by sector is proportional to the capital stock variation. Household consumption is endo genous, in real terms. Aggregated employment is fixed, being the real wage the variable that adjusts between the productive sectors to ratify the fixed total labor employment. However, labor is free to move between sectors and regions, guided by real wage differentials.

The government deficit is exogenous at the national level. Considering the simulations involves the introduction of a tax over emissions, the government budget neutrality is obtained through the devolution of the equivalent tax collection to the society, via a subsidy to the household consumption. The trade balance, as a share of the GDP, is endogenous, and the Consumer Price Index is the model's numeraire.

This closure gives the simulations a long run flavor, in the sense that the time period is long enough for capital to accumulate, as well as for the real wages to adjust.

\section{Results}

In what follows, the results of the simulations are presented and discussed. Initially, Table 3 shows some macroeconomic results in order to establish a basis to 
Table 3. Model Results. Selected Macroeconomic Variables. Percent Variation

\begin{tabular}{lccc}
\hline \multicolumn{1}{c}{ Variable } & carbtax05 & carbtxat & carbtax05x \\
\hline Real GDP & -0.32 & -0.00 & -0.39 \\
Capital stock & -0.60 & -0.20 & -0.88 \\
Household real consumption & -0.05 & -0.50 & -0.54 \\
Real investment & -0.60 & -0.20 & -0.88 \\
Balance of Trade/GDP & -1.02 & 2.99 & 1.47 \\
Exports (quantum) & -2.77 & 6.14 & 2.39 \\
Imports (quantum) & -0.45 & -0.35 & -0.83 \\
Terms of trade & 0.34 & -1.13 & -0.76 \\
Real devaluation & 0.30 & 2.05 & 2.34 \\
Real wage & -0.25 & -0.80 & -1.03 \\
Total emissions of CO2 eq. & -0.82 & -6.83 & -4.96 \\
\hline
\end{tabular}

analyze the sectoral results.

The values in Table 3 represent percentage changes results in the selected variables, caused by the policy shock introduced (the carbon tax). As it can be seen, the fall in GDP is larger in the first scenario (CARBTAX05), where the tax is introduced on fossil fuels only, than in the second scenario (CARBTAXAT), where the tax is on non-fossil fuels sources. The contrary however is observed on emissions, which falls by only 0.82 per cent in the first scenario compared to about -6.83 per cent in the second one. The third scenario (CARBTAX05X) combines the first two, and generates the largest fall in GDP, but with an emissions reduction which is smaller than the observed in the second scenario.

These results make it clear that, for the particular emissions matrix in the Brazilian economy, any policy to reduce emissions via taxation must also include the taxation on emissions linked to activities. As it can be seen, the third scenario (CARBTAX05x), which differs from the second scenario just for the inclusion of taxation on activity emissions, would result in a 4.96 per cent reduction in total emissions, at an almost identical cost in terms of GDP loss.

These results are strongly linked to the behavior of household consumption and exports in the model. It is worth to notice that the carbon tax is introduced on fuel use emissions as a tax on fuel prices, which affects the economy as a whole, and especially the sectors which are more intensive in fuel use. In the first scenario household consumption, which is concentrated on manufacturing, food and services, almost doesn't change, since the observed increase in the prices of food and manufacturing (to be seen bellow) is counterbalanced by a fall in the prices of 
services. However, the production costs increase caused by the tax translates into an export price increase for some sectors, and the fall in GDP is driven mainly by the fall in exports. In particular, Mining and Metallurgy products, especially Metallurgy of Iron present the largest fall in exports. This last sector (which is included in the Metallurgy aggregate) is the main user of Coal, and is particularly affected by the increase in the price of this input, caused by the carbon tax on fuels. As a result, the aggregated exported "quantum" index falls by 2.77 per cent in the first scenario.

In the second (CARBTAX) scenario, on the other hand, there is a strong increase in exports leaded by Mining and Manufacturing products, whose price fall. These sectors have a comparatively smaller share of their emissions linked to the level of activity than Agriculture and Livestock, and are less affected by the introduction of the carbon tax. Even though in this scenario household demands fall more than in the first one, mainly due to the increase in the price of agricultural and livestock products and, by consequence, of food, this increase is outweighed by the strong export push.

Note that the export increase is based on goods other than those based on agricultural and livestock products. The increase in agricultural prices causes a strong reduction ( -32.82 per cent) in Food exports, which are the relevant agricultural and livestock based exports in the model. Raw agricultural products and livestock are almost not exported in the base year, with the exception of soybeans (1.5 per cent of Brazilian total exports) and "other agricultural products $(0.5$ per cent of total exports). Food exports, on the other hand, accounts for 20.8 per cent of the total Brazilian exports in the database, and its export price increases by 0.78 per cent in the CARBTAXAT scenario. This increase in the prices of food is mainly driven by the strong increase in the prices of livestock (livestock, milk, other animals), which are some of the main inputs in the Food industry.

Figure 2 shows model results for the productive sector's activity level percent variation. In this figure, the thirty eight original sectors in the model were aggregated for presentation purposes in eleven broad sectors: Agriculture, Livestock, Forestry, Mining, Metallurgy, Manufacturing, Food, Ethanol, Fossil Fuels, Gasoethanol, and Services. The composition of these broad sectors definitions can be seen also in Table 1.

An interesting point to be noted from Figure 2 is related to the Forestry sector. As it can be seen, the activity level of this sector increases considerably in the simulations where the carbon tax incidence is on emissions linked to the activity 
Figure 2. Activity Level of Production Sectors Variation (\% change).

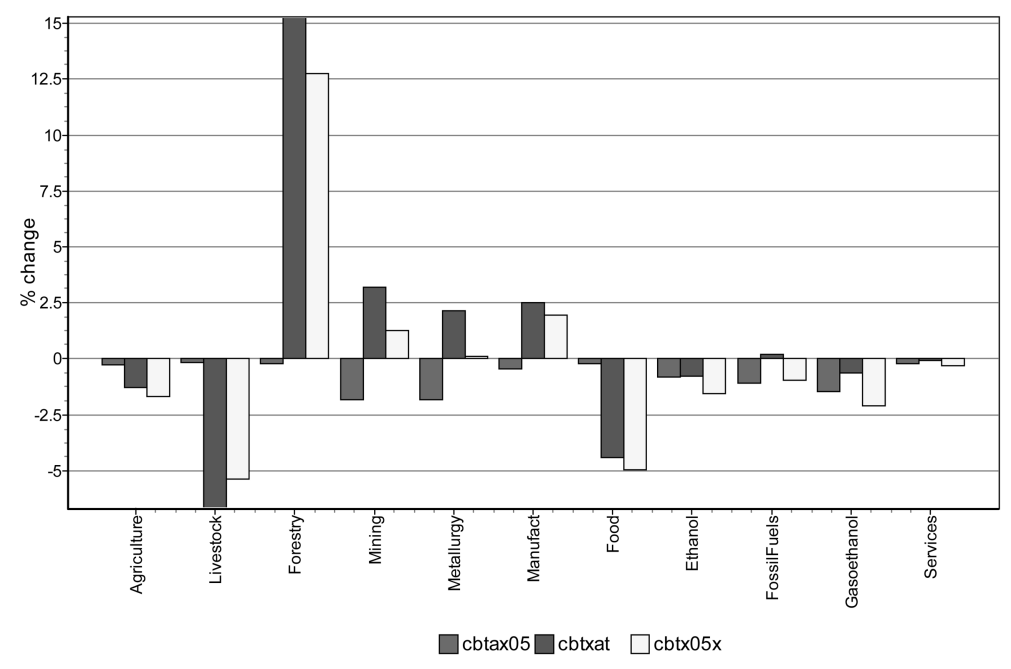

level. This happens because this sector is actually a carbon sink, that is to say, it has negative emissions on the initial database. The equivalent tax on this sector, then, is actually a subsidy which raises its profitability and, consequently, its activity level.

In the CARBTXAT scenario, where the carbon tax is introduced only on emissions linked to the activity level, there are still other results that should be noticed, like the strong reduction on the activity level of Livestock. As seen before, the Livestock sector is one of the most important $\mathrm{CH} 4$ emitting sectors in the economy, an emission that is linked to the sector's level of activity. In the absence of technological change the sector can't avoid the tax, which is fully charged on its product prices, causing the related increase in food prices. Other sectors, however, like the Mineral Extraction and Iron Metallurgy show an increase in production. These are sectors where the emissions are mainly associated to fuel use, and not to the activity level. In these cases, the increase in exports, caused by the real exchange rate devaluation and the fall in export prices, causes the increase in activity level.

In other cases, as is the case of the Metallurgy of Non-ferrous Metals, although there are emissions associated with the overall level of activity, the effect of the introduction of the tax is compensated by the increase in exports, since they represent a share of approximately 20 per cent of total use in the economy in the base year. This is an example of cases where opposing forces are at work in the wake of emissions taxation. 
Figure 3. Model Results. Percent Variation in Emissions of $\mathrm{CO} 2$ Equivalent, according to the Emitting Source.

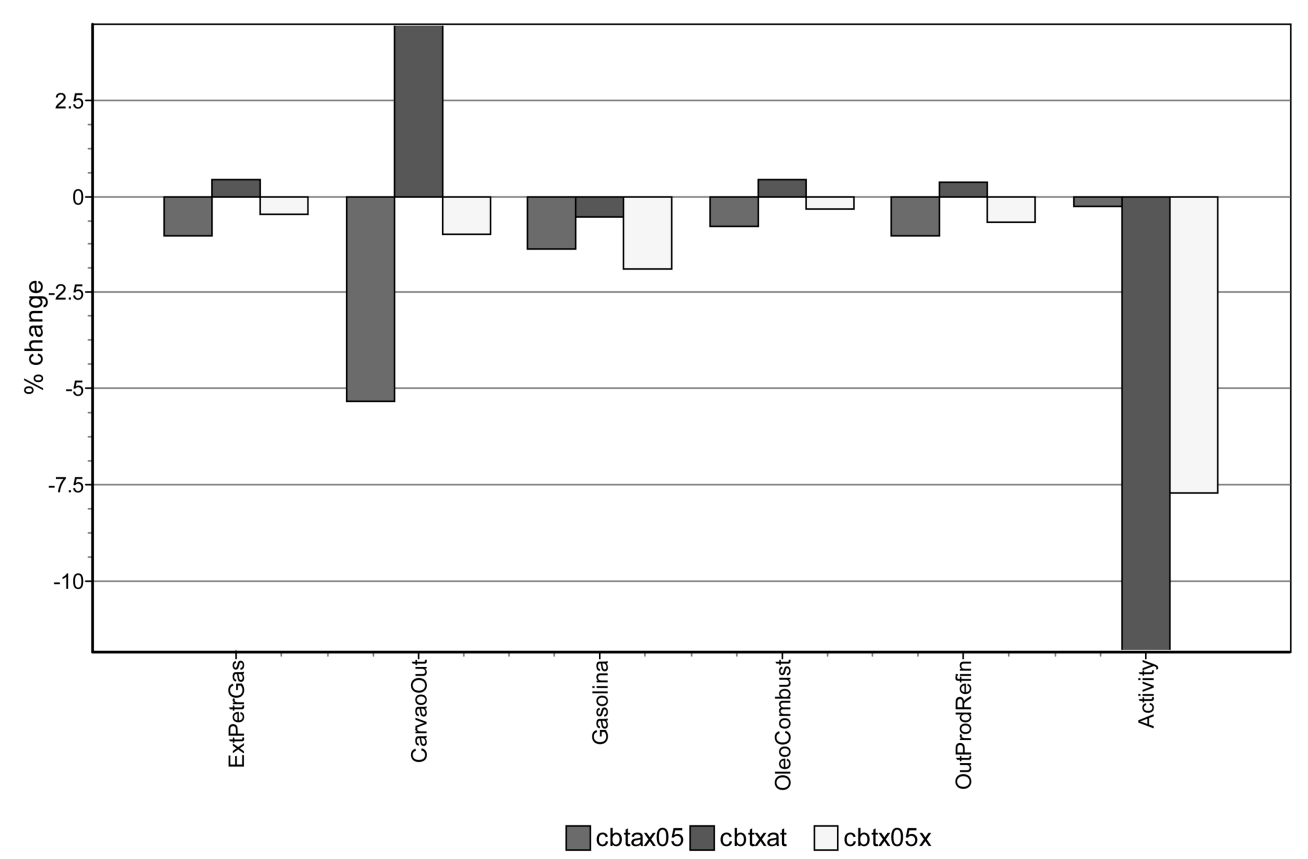

Another useful way of looking at the results is to analyze the variation of emissions in each scenario by emitting source, which can be seen in Figure 3. It can be seen from Figure 3 that the reductions in emissions originating in fuel use are larger, in general, in the scenario where the carbon tax is imposed only on fuel use, being the exception gasoline, whose emissions reduce more in CARBTAX05x than in the first two scenarios. To see why this happens, it is necessary to go back to the results in Table 3, which shows the macroeconomic results from the model. It can be seen there that the household consumption falls more in the simulations which involve only the tax over the level of activity than in those where the tax is over fuel use only. The product gasoline is sold basically for gasoethanol production, which is consumed almost entirely ( 81.9 per cent of total use) by the households. The fall in household consumption, then, causes an additional fall in the use of gasoline, derived from the fall in the consumption of gasoethanol. The same doesn't happen to the other fuels in the model. ${ }^{17}$ The larger reductions in emissions

\footnotetext{
${ }^{17}$ Even the product Other Refined Products, which is basically gas used for cooking (GLP) has its consumption considerably more distributed in the economy, being the households responsible for just 26 per cent of its total consumption.
} 
associated to the level of activity appear, of course, when activity is also taxed (two last scenarios).

It can be seen, then, that the greater efficiency of taxation on emissions linked the activity level of the production sectors, when compared to taxation on fossil fuels only, is caused by some particular circumstances related to the structure of the Brazilian economy. In the first place, due to the particular characteristics of the energy matrix in Brazil the bulk (61 per cent) of emissions (in $\mathrm{CO} 2$ equivalents) in the country are associated with the activity of sectors, and not on fossil fuels burning. Taxing these emissions, then, is more comprehensive than taxing just fuel.

Second, it is harder for the agents to avoid the tax on activities than in fuels, ${ }^{18}$ due to the existence in Brazil of a fuel, the ethanol, which is not a fossil fuel, and is not directly affected by the taxation. This allows for some substitution in fuel use, mainly for households direct usage decision on ethanol/gasoethanol, a substitution that may increase in time with the increase in the flex fuel engine fleet. The blend of ethanol and gasoline in the fuel used in the country (the gasoethanol) also helps to soften the price increase induced by the taxation on gasoline.

And, finally, most of the emissions linked to the activity level of sectors in Brazil are associated with the Agriculture and Livestock sector production, and are originated in $\mathrm{CO} 2$ and N20 emissions. Agriculture and Livestock are the main inputs in food production, and taxation on these emissions reduces more household consumption than in the case of taxation on fuels. Consumption is the most important element in absorption, and its decrease allow a compensating increase in exports other than food that keeps GDP barely unchanged in the simulation. ${ }^{19}$

The percent variations in emissions levels, by production sector in the model, can be seen in Figure 4. In this figure, attention should be called to the fact that the results showed for the forestry sector (Forestry) should be interpreted with a opposite signal, since this sector is actually a "carbon sink", and have negative emissions in the initial database. In this way a 12.75 per cent variation in this sector's emissions in scenario CARBTAX05X means that variation over a total of $46,230 \mathrm{Gg}$ of $\mathrm{CO} 2$ equivalent in the base year, or a reduction of $5,984.33 \mathrm{Gg}$ of $\mathrm{CO} 2$ equivalent in that scenario. Whenever Forestry increases its activity level, it will be reducing the associated emissions.

\footnotetext{
${ }^{18}$ Actually, in this version of the model there is no way a sector can avoid the taxation on its activity but due to technological change, which is not being considered here.

${ }^{19}$ Note that this increase in exports is facilitated by a exchange rate devaluation in the CARBTAXAT scenario.
} 
Figure 4. Model Results. Percent Variations in CO2 Equivalents, by Sector.

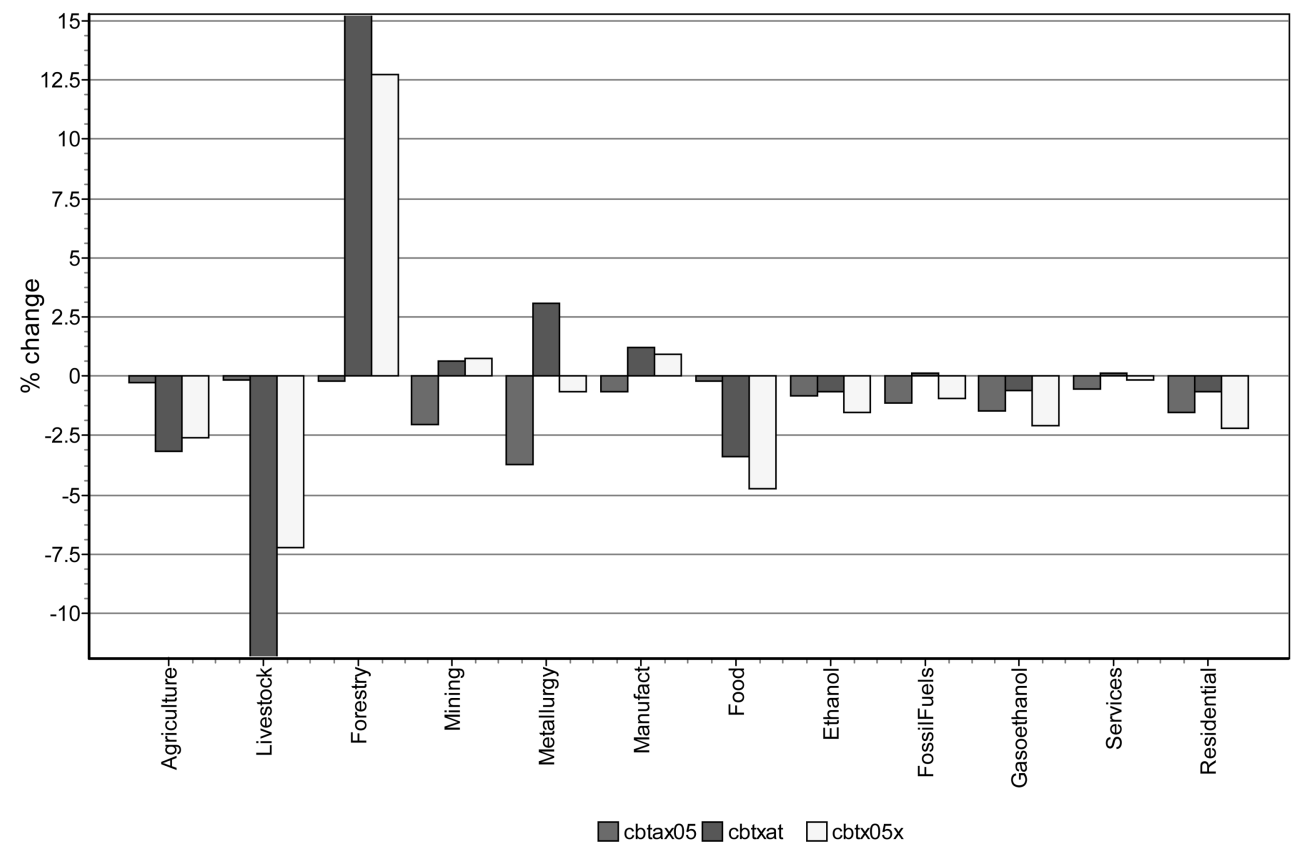

The results analyzed so far raise important questions for the introduction of a carbon tax on the Brazilian economy. As discussed previously, the introduction of the carbon tax on emissions linked to the level of activities are more effective in terms of emissions reductions, due to the importance of these emissions in Brazil. It was also shown that the agricultural related producing sectors are one of the most important emitting sectors of the economy, mostly with emissions associated to the sector's level of activity. The imposition of a carbon tax on these emissions, then, being implemented through an equivalent tax on products, would probably have important distributive consequences, since the burden of the tax on agriculture would have to be transmitted to food prices. This effect can be evaluated in Figure 5. As it can be seen from the figure, the increase in prices of raw agricultural products would reflect in an increase in the price of food of 2.45 per cent and 2.63 per cent respectively in scenarios CARBTAXAT and CARBTAX05x, where the emissions linked to the activity level are taxed. Actually, food prices show one of the largest price increases in these scenarios.

As mentioned previously, the economic activity in Brazil is unevenly spread in geographical terms, with the bulk of manufacturing sectors production concentrating on the Southeast region of the country. Agriculture and livestock production 
Figure 5. Model Results. Consumer Prices Variation.

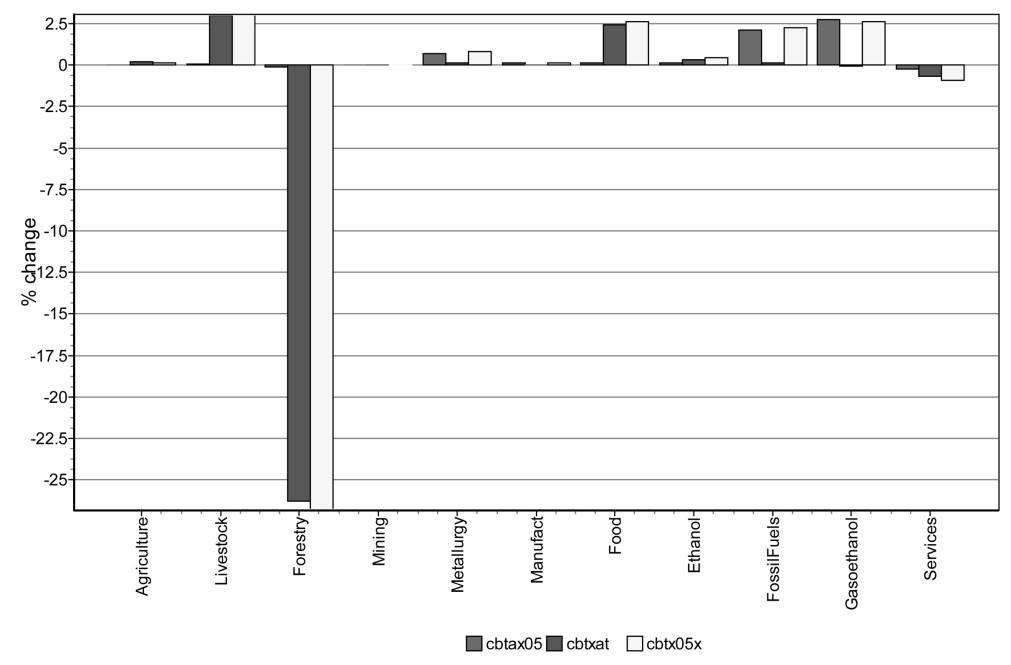

activities, on the other hand, have a larger share of GDP in the other regions, compared to the Southeast. The emissions composition, then, is also unevenly distributed over the territory, with the Southeast region concentrating relatively more emissions on $\mathrm{CO} 2$ linked to fuel use (Combustible Oil, mainly) and the Center west region with relatively more emissions of $\mathrm{CH} 4$ linked to the activity level of the Livestock sector (see Table 2). It is straightforward, then, that the different simulated policies can have different outcomes on the regions. This information can be seen in Figure 6, which shows the Gross Regional Product variation, by region.

As it can be seen from Figure 6, the real Gross Regional Product (GRP) in the Center West, North and South regions are particularly sensitive to the scenarios where the carbon tax is imposed on the emissions linked to activities (CARBTAXAT and CARTAX05x). These scenarios, on the other hand, generate an increase in the GRP of the Southeast region, and the contrary happens in the scenarios which charge the tax on fuels only. It can be seen, then, that the Northeast $\mathrm{t}^{20}$ and Southeast regions would be particularly sensitive to a carbon tax on fuels, while the South and Center West regions would be more sensible to taxation on activities. The North region would be sensitive to both kinds of taxes.

The taxation on fossil fuels affects negatively all producing sectors in the

\footnotetext{
${ }^{20}$ The result for the Northeast region, then, agrees with was found by Hilgemberg (2002), as seen before.
} 
Figure 6. Real Gross Regional Product (GRP) Variation.

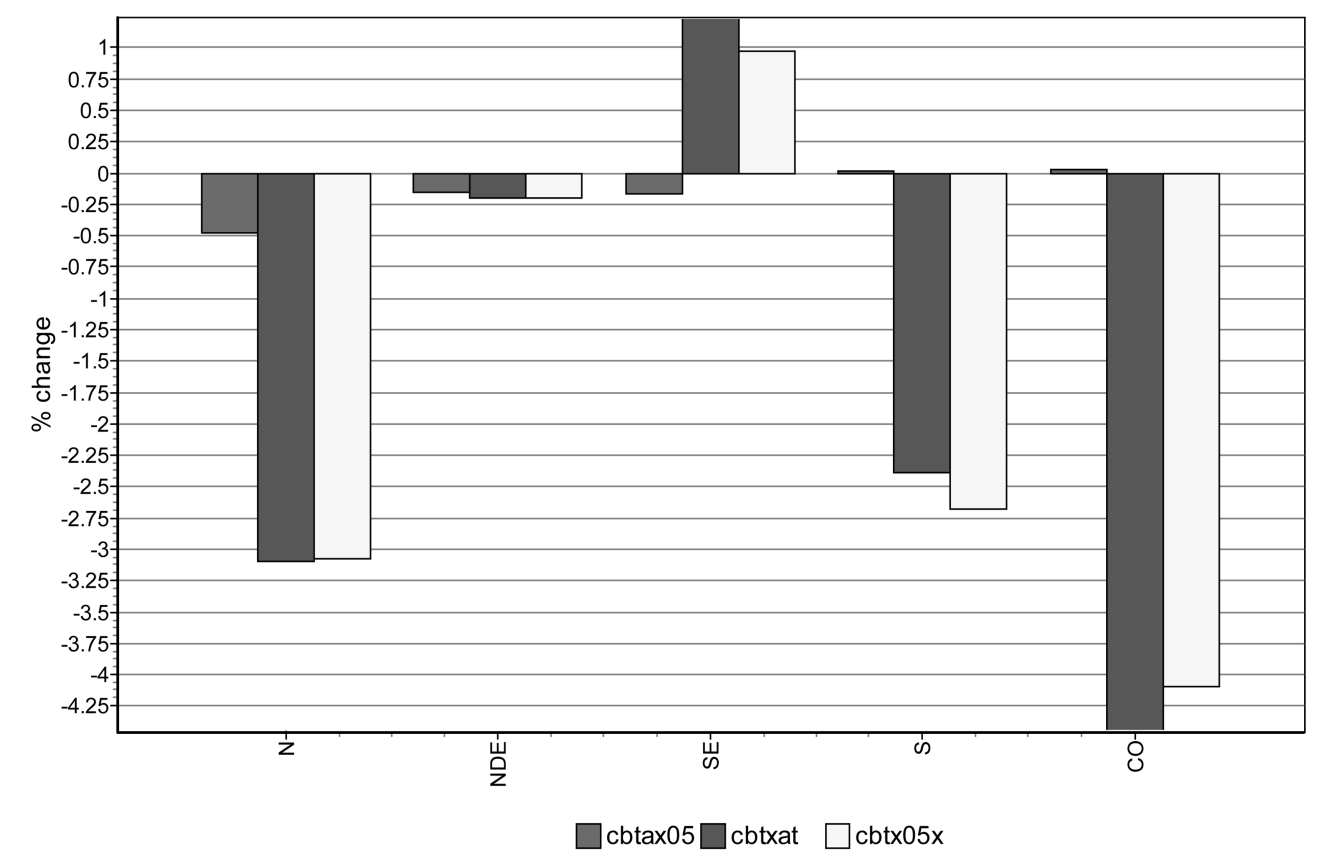

economy, as was seen in Figure 2. Taxation on emissions linked to the level of activity, however, has beneficial impacts on some sectors, like Forestry (carbon sink) and Manufacturing, Metallurgy, and Mining (export push, as seen before) and negative impacts on other sectors, as is the case of Livestock. These producing activities have different importance for the regional economies, and this causes the regional gross product to increase in some regions and decrease in others. The activity level variation of the aggregated sectors, by region, can be seen in Figure 7.

It can be seen from Figure 7 that most of the national expanding sectors (Forestry, Mining, Metallurgy, Manufacturing, mainly) are expanding more in the Southeast than in the other regions. ${ }^{21}$ These regions are also responsible for an important share of total production value in that region. In particular, Manufacturing accounts for about 22 per cent of total value of production in the Southeast, the second most important sector in the region, after only the Services sector.

\footnotetext{
${ }^{21}$ Note that these broad aggregates have different regional composition. The automobiles industry, for example (Machine and Vehicles), which is included in Manufacturing, is concentrated in the Southeast region, and shows a strong expansion in scenario CARBTAXAT.
} 
Figure 7. Model Results. Scenario CARBTAXAT. Activity Level Variation of Producing Sectors, by Region. Percentage Change.

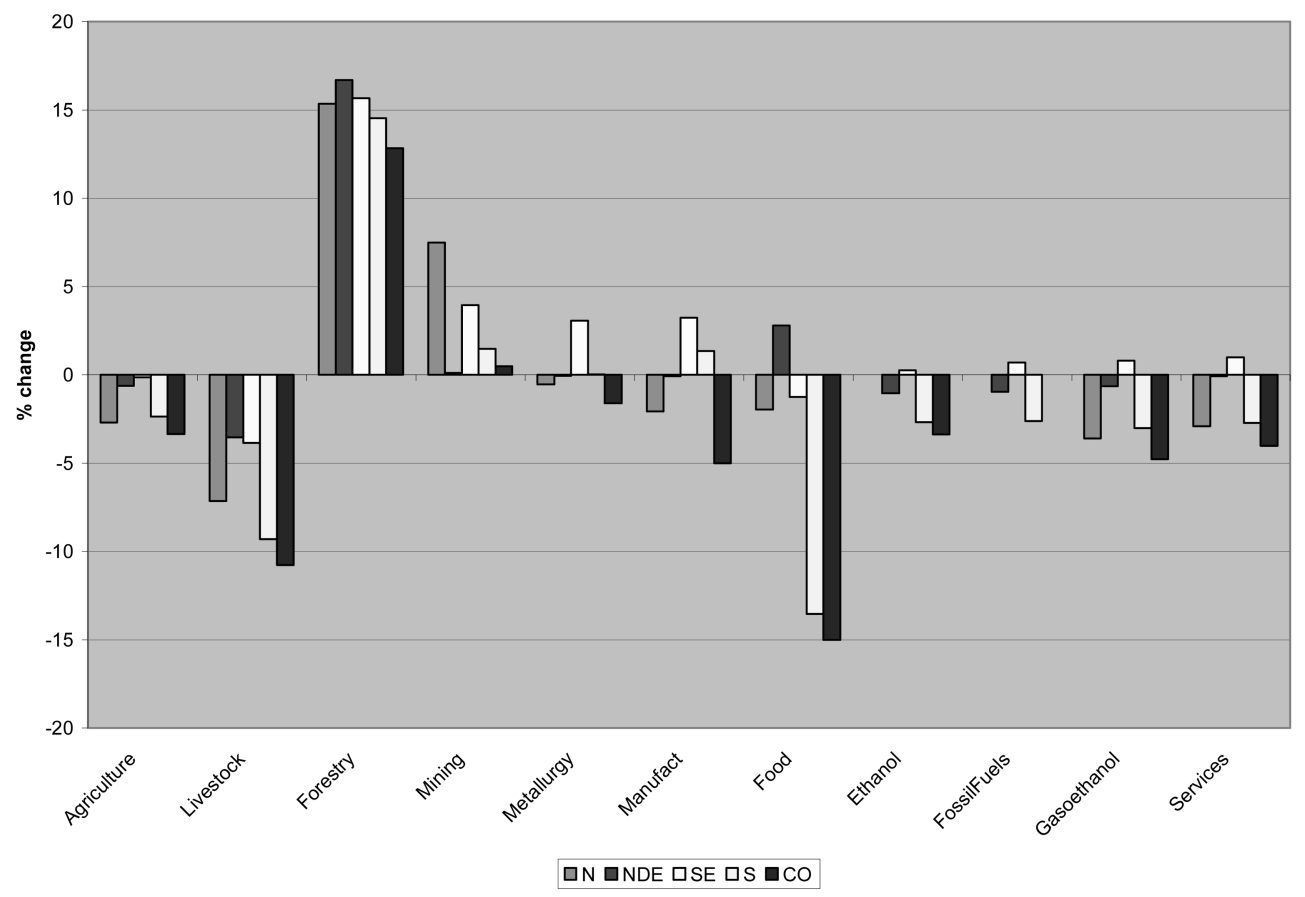

It was seen before (Table 3) that the fall in national GDP is smaller in the CARBTXAT scenario (tax on emissions linked to activity only) than in the other scenarios that include taxation on fuels. This result is a consequence of the regional adding up presented above, where the increase in the Southeast GRP compensates for the fall in the other regions. This fact raises an issue of particular interest for policy formulations, due to the political economy questions associated, namely the trade off of the policy result across regions in Brazil: the decision about which type of policy to adopt will involve also a decision about gainers and losers in regional terms.

It is apparent, then, that there is no easy choice arising from this analysis. As pointed out by Ferreira Filho and Horridge (2006), the states in the Northeast regions in Brazil are among the poorest, with the highest poverty headcount ratio. The most efficient policy in terms of emissions reductions (measured in terms of GDP loss) is the taxation on activity only, but this option seem to be also the most compromising one in distributive terms, both for the increase in the price of food, and also for the impacts on the poorest region's GRP. 


\section{VIIII. Sensitivity Analysis}

As mentioned before, the value of the elasticity of substitution between ethanol/ gasoethanol is an unknown parameter value for Brazil. For this reason, a sensitivity analysis was performed, changing the value of 0.5 used in the simulations described so far to 1.0. This new scenario will be identified as CARBTAX1.

The use of a higher value for this elasticity doesn't change the macroeconomic results presented before, which are exactly the same as in scenario CARBTX05. The introduction of a carbon tax on fossil fuels makes gasoethanol relatively more expensive than ethanol, leading to substitution towards ethanol, which is more intense the higher the value of the substitution parameter. The imposition of a tax on emissions linked to fuels use reduces the activity level of the ethanol producing industry less in scenario CARBTAX1 (-0.41 per cent) than in scenario CARBTX05 $(-0.81$ per cent), and inversely for the gasoline producing industry, with values respectively of -1.67 per cent (CARBTAX01) and -1.43 per cent (CARBTX05). As a consequence the reduction in total emissions is slightly smaller in scenario CARBTAX01, -0.84 per cent, compared to -0.82 per cent in scenario CARBTX05.

These results point to the fact that the ethanol producing sector is likely to be less sensitive to the introduction of the carbon tax on fuel use as the share of flexfuel engine vehicles in the fleet increases (which will increase the easy of substitution between gasoethanol/ethanol). As noticed by Giesecke et al. (2007), presently the flex fuel engine vehicles account for about 20 per cent of the Brazilian light vehicles fleet of 21.4 millions units. According to Petrobras (2007) this share is expect to grow to 70 per cent of a fleet of about 40 millions vehicles in 2020 (Giesecke et al., 2007).

\section{Conclusions}

As it can be seen from the above discussion, then, the introduction of a carbon tax on the economy has complex impacts, with differentiated results upon different production sectors and regions. The particular way of tax incidence, whether on fuels, activity of both, the sectors to be included in the policy and other structural details of the economy decisively affects the outcomes of the policy.

The results here presented highlight the importance of the emissions linked to the activity level of the firms for the Brazilian economy. Emissions taxation policies would be more effective if incident also on emissions linked to the activity level of 
the production sectors, instead of just on fossil fuels use. The results show that the aggregate social cost of these policies (in terms of GDP reduction) would be practically the same, with a reduction in emissions significantly higher in the second case. This kind of policy, however, would have important implications for the increase in price of food, with potential negative effects on poverty. This last aspect of the problem must be further evaluated in future works.

Another important point which appears in this study is related to the regional breakdown inside Brazil. The different spatial concentration of the economic activities generate particular pattern of emissions across regions. The different carbon tax system to be chosen, then, have different regional effects, with taxation on fuels harming more the Southeast and Northeast regions, and taxation on activity levels affecting negatively more the South and Center west regions. This fact turns evident an important trade off of these different policy options, one that is complex in political economy terms in a federative political system like the Brazilian one, since the policy choice will involve also choosing winners and losers. Again, the regional results suggest that the most efficient policy in terms of GDP reduction would also harm more the poorest regions.

Received 30 June 2007, Revised 8 March 2008, Accepted 9 April 2008

\section{References}

ADAMS, P.D; HORRIDGE, J.M; WITTWER, G. MMRF-GREEN: A Dynamic Multiregional Applied General Equilibrium Model of the Australian Economy, Based on the MMR and MONASH Models. Monash University, Centre of Policy Studies. 70 p. November, 2002.

BRASIL. Ministério da Ciência e Tecnologia. Coordenação Geral de Mudanças Globais do Clima. Comunicação Nacional Inicial do Brasil à Convenção-Quadro das Nações Unidas sobre Mudança do Clima. 2004 (Disponível em: http://www.mct.gov.br/ index.php/content/view/21037.html).

FERREIRA Fo; J.B.S; HORRIDGE, J.M. The Doha Round, Poverty and Regional Inequality in Brazil. In: HERTEL, T.W; WINTERS, A. (eds). "Putting Development Back into de Doha Agenda: Poverty Impacts of a WTO Agreement”. 2006, World Bank. Washington, DC.

GIESECKE, J.A; HORRIDGE, M.J; SCARAMUCCI, J.A. The Downside of Domestic Substitution of Oils and Biofuels: Will Brazil Catch the Dutch Disease? General Paper no. G-169. Centre of Policy Studies, Monash University. December, 2007 (available on line at http//www.monash.edu.au/policy). 
HILGEMBERG, E.M.; GUILHOTO, J.J.M.; HILGEMBERG, C.M.A. T. Uso de Combustíveis e Emissões de CO2 no Brasil: um Modelo Inter-regional de Insumo Produto. In: XXXIII Encontro Nacional de Economia, Natal, 2005. (Disponível em: http://www.anpec.org.br/encontro2005/artigos/A05A135.pdf)

IPCC. Climate Change 2007: The Physical Science Basis - Summary for Policymakers. 2007. (Disponível em: http://www.ipcc.ch/SPM2feb07.pdf)

IBGE - INSTITUTO BRASILEIRO DE GEOGRAFIA E ESTATÍSTICA. Censo Agropecuário do Brasil. 366p.Rio de Janeiro, 1996.

IBGE - INSTITUTO BRASILEIRO DE GEOGRAFIA E ESTATÍSTICA. Pesquisa Nacional por Amostra de Domicílios. Brasil, 2001.

IBGE - INSTITUTO BRASILEIRO DE GEOGRAFIA E ESTATÍSTICA. Pesquisa de Orçamentos Familiares. Brasil. 1996a.

LOPES, R.l. Efeitos de uma Restrição na Emissão de CO2 na Economia Brasileira. Tese (Doutorado). Piracicaba, 2003.

PETROBRÁS. Biocombustíveis e a Economia Brasileira. (M.S.Queiroz). Conferencia Nacional de Bioenergia (Bioconfe). São Paulo, Brazil. 2007.

TOURINHO, O.A.F.; DA MOTTA, R.S.; ALVES, Y.L.B. Uma Aplicação Ambiental de um Modelo de Equílibrio Geral. IPEA. Texto para discussão n. 976, Rio de Janeiro, 2003. (Disponível em: http://www.ipea.gov.br/pub/td/2003/td_0976.pdf)

United Nations Framework Convention on Climate Change - UNFCCC. Convenção sobre Mudança do Clima. 2.ed. Brasília: MCT, 2001a. 30p. (Disponível em: http:// www.mct.gov.br/index.php/content/view/3996.html)

United Nations Framework Convention on Climate Change - UNFCCC. Protocolo de Quioto. 2.ed. Brasília: MCT, 2001b. 34p. (Disponível em: http://www.mct.gov.br/ index.php/content/view/4006.html). 